\title{
Daśāvatāras in Tamil bhakti literature and programme of sculptures in Vijayanagara-Nāyaka art
}

\author{
S. Ganeshram
}

Sri S.R. Naidu College, Sattur, Tamilnadu, India

\begin{abstract}
The term daśävatāras stands for the ten incarnations of Viṣnu. They are Matsya, Kūrma, Varāha, Nṛsimha, Vāmana / Trivikrama, Parasurama, Rama, Balarama, Krishna and Kalki. These are noted in the hymns of Ālvārs in orderly or disorderly pattern. The first part of the article discusses the significance of a set of daśāvatāra images in the Kaḷarpirān temple at Śrīvaikuṇțam in Tirunelveli district. Such images in separate enclaves were set in Vijayanagara-Nāyaka period (15th-18th centuries CE) temples in Tamilnadu, e.g. Tătikkompu and Alakarkoyil. To this milieu the images examined in the article add a new dimension.
\end{abstract}

Keywords: Ālvārs, Śrīvaikuṇțam, Vișṇu, daśāvatāra, Matsya, Kūrma, Varāha, Nṛsimha, Vāmana / Trivikrama, Parasurama, Rama, Balarama, Krishna, Kalki, Vijayanagara-Nāyaka. 
During the Vijayanagara-Nāyaka period the daśāvatara sculptures came to be programmed in a continuous array. ${ }^{1}$ Śästras may talk of the daśävataras in a sequential order ${ }^{2}$, starting with Matsya and ending with Kalki but sculptural representations in such an order may be rare. An early example of such a fixation may be found in the Pāpanāseśvara temple at Alampūr of the Eastern Cālukyan denomination, dated around the 8th century CE (Kalidos 2006: I, 18788). Set within a square mandala, the Buddha appears in the center. ${ }^{3}$ Such a setting of the daśāvatāra images acquired popularity in Vijayanagara-Nāyaka art. ${ }^{4}$ The present communication examines such a group of sculptures from Kallarpirān temple at Śrīvaikunțham. This huge temple complex takes its origin during the later Pāndydya period in the 12th-13th century CE but most of the mandapas therein are Vijayanagara-Nāyaka additions (Ganeshram 2010: Chap. III). The daśavatāra sculptures under note are set in one of the mandapas. The same type of images appear in the Viṣnu temples at Tātikkompu ${ }^{5}$ near

\footnotetext{
${ }^{1}$ The daśāvataras are Matsya (Fish), Kürma (Tortoise), Varāha (Wild Boar), Nṛsimha (Man-Lion), Vāmana-Trivikrama (the Dwarf and Virāt), Paraśurāma (Rāma with the Battleaxe), Balarāma, Kṛ̣ṇa, Dāśarathi-Rāma and Kalki (Basham 1971: 30449).

${ }^{2}$ See the Śritattvanidhi (1.2. 47-57) for such an order. The list includes both Kṛșna and the Buddha. It is possibly cited from the Padma Purāna. At the end of the list the varna of each avatāra is given. The personalities (colour within parentheses) listed are the following: Matsya (sphațika), Kürma (svarṇa), Varāha (nīla), Nṛsimha (white as moon), Prahlāda (golden), Vāmana (nīla or black), Paraśurāma (svarṇa), Rāghava (green), Bharata (green), Lakṣmaṇa (golden), Satrugna (red), Sìtā (svarṇa), Māṇụavī (red), Ūrmilā (green or blue), Sṛtakīrtī (white), Hanumat (kanaka, pale red), Añgada (red), Sugrīva (svarṇa), Jāmbavat (of the colour of nīlotpala), Guha (kanaka), Bibhiṣaṇa (black), Balarāma (milk white), Revatī (red), Kṛṣna (megavarṇa), Rukmiṇī (kanaka) and Kalki (white). The Buddha is not brought under this list.

${ }^{3}$ The Māmallapuram Pallava inscription includes the Buddha among the daśāvatāras of Viṣnu (Srinivasan 1964: 173) and omits Kṛ̦nạ. Others are Matsya, Kūrma, Varāha, Nrrsimha, Vāmana, the three Rāmas and Kalki.

${ }^{4}$ Raju Kalidos (1989: 338-40, figs. 35, 43; cf. 1988: 98-125) has reported not less than 47 occurrences in the temple cars of Tamilnadu. Most of these temple cars are of the Nāyaka or post-Nāyaka period.

${ }^{5}$ This temple is noted for its artistically set mandapa with sculptural pillars in the shrine for Lakșmī (Gopalakrishnan 1996: 415-31). The temple was rebuilt during the period of Veñkațpati Rāya and is dated in Sälivāhana era 1551 (CE 1629) that falls during the time of Tirumalai Nāyaka (CE 1623-59) of Maturai.
} 
Tintukkkal, and Alakarkōyil ${ }^{6}$ near Maturai, both called Saundararāja and both are of the Nayyaka period. The canonical setting for the presentation of the images may be found in the Tamil bhakti hymns of the Ālvārs of the early medieval period (c. CE $550-850)^{7}$, which literature had a far reaching impact on the arts of the land.

\section{Daśávatāras in Tamil Bhakti Literature}

Before taking up the images for an examination, the literary mandate may be discussed to begin with. Tirumalicai, Nammālvār, Periyālvār and Tirumañkai Ālvār make a note of the clusters of the daśāvatāras. Casually it may be noted here that the works of the Ālvārs is collectively called Nālāyirativviyappirapantam, shortly Nālāyiram "the 4,000". Among the above mentioned four Ālvārs, Tirumankai is said to have converted the Pallava Emperor, Nandivarman II (CE 731-96) to Vaiṣnavism, who in his work Periya Tirumoli notes the sequential order of the daśâvataras in a number of places. Periyālvār seems to have converted the Pāṇụan Emperor Śrīmāra Śrīvallabha (CE 815-62). Tirumalicai and Nammālvār belong to an early group and may be dated in the 7 th or early 8 th century CE.

Nammālvār notes not less than five of the avatäras in an order. They are Matsya (Tamil Mīn), Kürma (Tamil Ämai), Nrssimha (Tamil Naracin̉kam or Cinkappirān - Periyālvār Tirumoḷi 5.2.4), Vāmana (Tamil Kural means “dwarf”, also called Mānikkuralạn - Periyālvār Tirumoli 1.4.1, 5.2.5, māṇi means brahmacāri, Kuratpiramaccāri Periyālvār Tirumoḷi 4.9.7), Varāha (Tamil Eূnam) and Kalki (Tamil Karki):

\section{Mīnāyāmaiyumāy naracinkkamumāy kuralạy}

Kān̄ārēenamumāyk karkiyāy (Tiruvāymoli 5.1.10).

Periyālvār notes the Haimsa, Matsya, Simha, Vāmana and Kürma in a sequence: ${ }^{8}$

\footnotetext{
${ }^{6}$ During the historic past, the place was known as Māliruncōlai (the place where Māl/Vișṇu) resides, noted in ancient Tamil literature such as Paripātal and Cilappatikāram (Rajarajan 1996).

${ }^{7}$ For a comprehensive picture of the Nālāyiram bearing on Vaiṣnava iconography see Kalidos 2006: Chap. I.

${ }^{8}$ The amśánvatāras according to the Devī Bhägavata are Sanaka, Sanandana, Sanādana, Sanatkumāra, Nārada, Nara-Nārāyaṇa, Kapila, Dattātreya, Yajna, Ṛṣabha,
} 


\author{
Anñamum mīnuruvu mālariyum kuralum \\ Ámaiyumānavan̄ē... (Tirumoli 1.7.11).
}

In these references the avatāras are not noted in the set order. Tirumalicai in two stay occurrences notes the Mohinī and Matsyāvatāras. Mohin̄i is called alakiyan "He, beautifully she". ${ }^{9}$ The Fish is one that gives life, mīnāyuyiralikkum (Nānnmukan Tiruvantāti v. 22). The Vāmana and Trivikrama (Tamil Tirivikkiraman Periyālvār Tirumoli 1.8 .9$)$ avatāras are beautifully coagulated in the phrase, Ciriyan mikapperiyan "the small (Dwarf) but at the same time very big (Virāt)" (Nānnmukañ Tiruvantāti v. 71). Periyālvār brings the ten in a hymn as noted in the following order: Mīn, Amai, Énam, Ari (Simha), Kural, the three Rāmas ${ }^{10}$, Kaṇnann (Kṛ̣̣na, Prākit Kanha) and Karki:

$$
\begin{aligned}
& \text { Tēvuțaiya mīnamàa yāmaiyāy } \\
& \bar{E} \text { ñamā yariyāyk kuralāy }
\end{aligned}
$$

Mūvuruvilirāmañāk kaṇnạ̣āyk

Karkiyāy muțippān ... (Tirumoli 4.9.9).

Pṛthu, Mohin̄̄, Garuḍa, Dhanvantari and Vyāsa (Kalidos 1986: 183n). Hamisa as an avatāra appears often in the Nālāyiram. The hymns note a "dancing bird", called Átarparvai (PT 9.9.10, Tiruvāymoli 8.2.4, 8.8.9). It is not clear whether this is Garuda (Chandramohan 2008: cover plate) or Hamisa. Besides, the Rämayanam (Bālakāndam, 5. Tiruavatārappațalam, v. 22) of Kampar considers Rāma, Lakṣmaṇa, Bharata and Satrugna as the avatāras of Viṣnu Ādiśeșa, śankha and cakra. Another avatāra-like form of the Lord is Hayagriva (Kalidos 2006: I, 16), the Horse-headed. He is said to have admonished a horse-headed demon: Pariyōn mārvakam parrippilantu (PT 7.7.5) "Caught hold of the chest of the horse (-demon) and cleaved it (cf. Nrsimha and Hiranya);" Nālvētapporulaiyellām parimukamāy aruliyaperumān (PT 7.8.2) "The Lord who divulged the meaning of the four-Vedas as the Horse-faced (hayasitiras or hayagrīva)."

9 Allaki means a damsel. $\bar{A} \underline{n}$ is a masculine suffix. Nammālvār adds: Aṇallaṇ pennallan "He is neither a man nor a woman" (Tiruvāymolli 2.5.9). Again it is added he is neither a man, nor woman and eunuch: annallan pennallan allāl aliyumallan (ibid., 2.5.10). Tirumalicai adds: Annin̄oțtu penṇumāki allavōtu nallavāy "He is both man and woman and neither of these, i.e. eunuch."

${ }^{10}$ The Vēlūr temple car houses an image of the three Rāmas appearing in a row (Kalidos 1989: fig. 43). The order is Paraśurāma (holds the paraśu), Dāśarathi-Rāma (carries the dhanus and bāna) and Balarāma (carries the halā "ploughshare"). 
Tirumalicai in his Nānmukan Tiruvantāti notes the Matșya and Hamsa avatäras of the Lord. The Hamsa is one who ordained the precious Scriptures:

$$
\begin{aligned}
& \text { Anñamāki arumaraikal arul (Periya Tirumoli hereinafter PT 5.1.9). } \\
& \text { Annamamākiyañaru maraikal payantavan (PT 5.3.8, 5.7.3). }
\end{aligned}
$$

Periyâlvar (Tirumoli 1. 10) elaborates the mythology saying that the gloom of pralaya encircled the cosmos. The four Vedas disappeared. The Lord incarnated as Hamsa in order that the gloom vanishes and that the Vedas are recovered.

Tirumañkai quite often brings the avatāras in clusters. The Swan, Fish, Lion, Dwarf and Tortoise appear in a disorderly order:

Annnamum mīnurumālariyum kuraḷm

Ámaiyumānavañē... (PT 1.7.11).

The word that denotes avatâra in this statement is annavan "he became". ${ }^{11}$ In another context the Boar, Fish, Tortoise, Lion and the Dwarf listed:

$$
\begin{aligned}
& \text { Ēñamīñāmaiyōtariyum cirukuralumāy } \\
& \text { Tāṇumāya... (PT 5.4.8). }
\end{aligned}
$$

Tānumāya here means "he himself became". Tirumañkai calls the Boar Pañi "pig" in another context. The avatāras listed here are Pig, Fish and Lion:

Pañriyāy mīnāki yariyāyp

Pāraippațaittuk kāttunțumilnta paraman (PT 7.8.9).

"The Eternal He came as the Pig, Fish and Lion to create the worlds, sustain, swallow and spit." 12

\footnotetext{
${ }^{11}$ The Tamil equivalent of avatāra is avatāram (cf. avatari in Kampa-Rāmāyanam, Bālakāntam, 5. Avatārappațalam, v. 20). The Manimēkalai (17. 1. 9), a 6th century Tamil epic, deploys the word mayanki (contextually transform, literally "swoon"): Netiyōn mañkinilamicaittōñ $i$ ("The Tall [Trivikrama] transformed himself and appeared on earth").

${ }^{12}$ The pancakrtyas (șrști/tōrram "creation", sthiti/kāttal "sustenance", samiāarra/ cañkāram "destruction", tirodhana/maraittal "embodiment" and anugrahal anukkirakam or vituvittal "release") are attributed to Viṣnu in this hymn. Cf. the Bhagavat Gīta (Chap. IV, vv. 7-8) version: Yadā yadā hi dharmasya glānirbhavati
} 
The Lion, usually called Ari, is called Cinkam, transcription of the Sanskrit simha, in a hymn:

Mīn̄ōrāmaiyumāy...cin̄kavuruvāy... (PT 8.4.4).

"The forms are Fish, Tortoise and Lion.,"13

Besides these cryptic references, Tirumankai has a hymn each on Varadarāja, Mohinī and Kṛṣna that appear in PT (8.9):

v. 1. Kaimā matayāñi yițar tīrtta karumukil

"The black cloud that removed the hardship of the elephant (Varadarāja)."14

v. 2. Tirumālai yammānai yamutattaik kațarkițanta perumānai

"Tirumāl/Viṣnu, the Father, the Dignified who extracted the ambrosia from the ocean (Mohinī)."

\section{v. 3. Vițaiyēlan ratarttu vekunțu vilanikalura}

Pațaiyāli tațta paraman Parancōti

"That day he admonished the seven wild bulls, the Eternal he holds the armed-disc, He is the Eternal Lamp (Kṛṣna)."

Another decad (PT 9.1) brings the Matsya, Varāha, Vāmana/ Trivikrama and Paraśurāma in four hymns in an order:

v. 3. Mīnuruvāki viripuñalvariya kațtatolittōn ...

"As a Fish he contained the inundating waters within his shell (Matsya)."

v. 4. Pañriyāy añru pārmakal payalai tīrttavañ...

"That day he removed the hardships of the Earth Maid, Bhūdevī (Varāha)."

Bhāratal Abhyutthānamadharmasya tadātmānaì srujāmyaham/l Paritrāṇāya sādhūnām vināśāya ca dușkrtām/ Dharmasamthāpanārtthāya sambhavāmi yuge yuge// "Bhārata (Arjuna) whenever dharma is destroyed and adharma shoots up, I make me born again. In order to protect the righteous, to admonish the evil and to establish righteousness, I am born again and again."

${ }^{13}$ For a comprehensive picture of Nrsimha from the Tamil bhakti hymns see Kalidos 1999: 168-78.

${ }^{14}$ This form is counted under the lìlāvatāras in the Bhāgavata Purāna (Kalidos 2006:

I, pp. 39-40). 


\section{v. 5. Mannnavan periyavēlviyir kuralay mūvați nīroținkoṇtu}

Pinnnumēlulaku mīrațiyākap perunticaiyațañkitanimirntōñ...

"He appeared as a Dwarf (Vāmana) in the big sacrifice of the King (Mahābali) and got sanctified the gift of three spaces of land; later grew Tall and compressed (measured) the seven worlds in two strides."

\section{v. 6. Maluvinal avañiyaracai mūvelukal maṇimuți poțipațuttu utirak}

Kulavuvār punaluḷuḷittu ven்kōpam tavirttavan ... ${ }^{15}$

"For twenty-six generations he (Paraśurāma) toppled the crowns of kings on earth and punished them with a battleaxe and got himself appeased."

Kulacēkara Ālvār (Perumāl Tirumoli 10) compresses the entire Rāmāyana from the Bālakānda to the Uttarakānda in decad bearing on the Cittirakūtam (Citrakūta) of Citamparam. ${ }^{16}$ Tirumañkai extols the Rāmāyana's little heroes in his PT 10.3. The personages do exalted are Sugrīva (called Sūrya-putra), sons of Sugrīva, the vānaras (monkey horde), Hanumat, Angada, Nala, Kumbhakarṇa, besides Rāma and Lakṣmaṇa. The pride of the demons Rāvaṇa and Indrajit were curbed.

Tirumañkai in his PT (8.8) summarizes the daśāvatāra activities in each of the hymns of a decad. ${ }^{17}$ The conventional order followed is Matsya, Kūrma, Varāha, Nṛsimhha, Vāmana/Trivikrama, Paraśurāma, Śrī Rāma, Balarāma, Kṛ̣ṇa and Kalki. The sthala is Kaṇṇapuram in Cōlanādu. The summary of the ideas may be presented as follows:

1. The lotus-eyed he appeared a Fish and rescued the gods when the primeval waters inundated the cosmos. He was the same Lord who appeared as Kṛṣna.

\footnotetext{
${ }^{15}$ Elsewhere it is said he cut the shoulders of 1,000 kings with the paraśu: Mannanccavāyirantōl maluvil tunittamaintā (PT 7.2.7).

${ }^{16}$ For a summary of this decad see Kalidos 1997.

${ }^{17}$ This decad deploys the following terms to mean an avatāra (cf. n. 9): vantu "came", $\bar{a} y, \bar{a} k i$ or $\bar{a} \underline{n} \bar{a} \underline{n}$ "became", ețuttu "took (contextually appeared)", tōn $\underline{r} i$ "appeared", vantutōñri "came and appeared" and pirantu "born".
} 
2. He appeared as a Tortoise when the Ocean of Milk was about to be churned and supported the Manthara mountain on his back.

3. When the primeval waters engulfed the worlds, the Lord appeared a Boar (in order to protect the Goddess of Earth).

4. The Lord presented himself a ferocious lion (agnilocana "fireemitting face" NA 8 or jvālämukha NA 23) mixed with the form of a man at which the gods were terrified. He cleaved the chest of Hiranya with his sharp diamond-like nails (vajranakha NA 54 or mahädamsțra NA 30).

5. He appeared a Dwarf whose form arrested the reverence of those that viewed the Lord and bagged three strides of land as a gift.

6. He appeared Paraśurāma carrying the dreadful weapon battleaxe and for twenty-six generations admonished the race of kings (kșatriyas).

7. He appeared Rāma when the mass of the worlds adored his sacred feet and he being the Lord worships none. He staged a war with Lankā and extradited the evil-beings.

8. He wears a kundala in an ear and holds the ploughshare, his arm. It was he who appeared as Balarāma (name not mentioned) and sent the soldiers (kșatriyas) at war with him to the heavens.

9. He (Krṣna $)^{18}$ was born in midnight to ward of the perils to which the Goddess of the Earth (metaphorically Draupadī) was subjected and staged the Bhārata war.

10. He became the Fish, Tortoise, Boar (kẹlal), Ari (Lion), Rāma (Paraśu) the First, Rāma (Dāśarathi) the Second, Dāmodhara ${ }^{19}$ and Kalki. He is the Lord of Kannapuram. ${ }^{20}$

\footnotetext{
${ }^{18} \mathrm{Kr}$ ṛ̣na is the most popular hero in the hymns of the Ālvārs (Kalidos 2006: I, 11-16). Kṛṣna and Dāmodhara are again equated in PT 10.5.3.

${ }^{19}$ Dāmodhara (cf. the KA epithet 96 Dāmodhara) is the equal of Kṛșna. He is one among the dvāsaśa and caturvimśati forms of the Lord. Interestingly both Kṛṣna and Dāmodhara do form members of these two groups of Vaiṣnava iconography (Caturvimśatimūrtilakșaṇa, p. 5). The dvādaśa are clustered in few of the Nālayyiram decades (e.g. Tiruvāymoli 2.7. all hymns).

${ }^{20}$ Each of the hymn in this decad is addressed to the Lord of Kannapuram (Kannan 2007). K. Kannan 2007 deals with the following Viṣnu temples in the Kāviri delta: Kaṇnapuram, Kaṇnamañkai, Cirupuliyūr and Nākapaț̣inam.
} 
Tirumañkai repeats the sequence of avatāras in PT 11.4. In this order Balarāma and Kalki are omitted and Haimsa included. The summary of ideas forthcoming from the decad may be summarized in the following account.

1. The waters of pralaya engulfed the worlds in such a way that there was not even a span of land to stand. The gods trembled and reported the matter to the Lord, seeking refuge under him. The Lord assured them lebensraum and drew all the waters into his stomach. ${ }^{21} \mathrm{He}$ is the Lord Minn/Matsya.

2. The gods churned the Ocean of Milk having tied the mighty Vāsuki to the Manthara. In order that the churn-stick, the Manthara, may stand firmly the Lord provided a basement to it as $\bar{A} m a i / K \bar{u} r m a$.

3. During the primeval times the Lord appeared as Enam/Varāha in order to protect the Earth. ${ }^{22}$ Sürya, Candra, the devas, the celestials worlds seven, the Meru hill, six mountains and seven seas constituted the hoof of the Boar. ${ }^{23}$

4. Garlands of flowers hung on either side of his (Nrsimha) eyes that emitted fire (cf. NA epithets supra). He is the most ferocious Lion who cleaved the chest of the demon (Hiranya).

5. As though a genuine Vedi (Vāmana), he went to the yāgaśălā of Mahābali and begged three strides of land. Once the grant was sanctioned his (Trivikrama) striding leg rose up above the

\footnotetext{
${ }^{21}$ This is part of his Viśvarūpa activity. Periyālvār in his Tirumoli i adds: Aṇtamum nātu mațanka vilunkiya "He gulped the cosmos and the lands" (cf. Maxwell 1983: 213-34, 1993: 97-110, Gail 1983: 297-307). The Nālāyiram in a number of places sheds light on the Viśvarūpa of the Lord. T.S. Maxwell and A.J. Gail may not have an idea of the Tamil vision (cf. Kalidos 2006: I, p. 19).

${ }^{22}$ This event is said to have occurred during the Varāhakalpa. In Hindu cosmogony "the cosmos passes through cycles within cycles for all eternity" (Basham 1971: 32526). The basic cycle is kalpa, a "day of Brahmā" that constitutes 4,320 million human years. The night of Brahmā is of equal length. A year of Brahmā consists of 360 such days and nights. He lives for 100 such years. The present Brahmā is said to be his 51 st year. Each kalpa consists of four manvantaras that last for 306,720,000 years. We are now in the seventh manvantara of Manu Vaivasvata. Each manvantara consists of 71 mahāyugas or aeons. A kalpa consists of 1,000 manvantaras. Each mahāyuga consists of four yugas or ages, called Kṛta, Treta, Dvāpara and Kali, each of 4,800, $3.600,2,400$ and 1,200 "years of the gods". Each year of the god is equal to 360 human years.

${ }^{23}$ Cf. the colossus of zoomorphic Varāha from Eran (Williams 1983: figs. 198-200).
} 
summit of the Manthara Mountain, which was worshipped by the God seated on flower (Brahmā).

6. He (Paraśurāma) admonished the rulers of the earth on twenty-one occasions by employing the terrific weapon, paraśu. He is the Lord of Nilamankai (Bhūdevī), Malarmañkai (Lakșmī) and Pulamañkai (Nīlādevī). ${ }^{24}$

7. He (Śrī Rāma) is our Guard who identified the māyāmrga (Mārīca) and shattered the army of the King of Lankā.

8. Once upon a time the seven worlds were immersed in darkness. The gods could not find out where the beginning is and where end is ( $\bar{a} d i$ and anta). The Vedas disappeared. The Lord (Annam/Hamsa) took pity on the gods and sages, appeared as Swan and preached the Scriptures.

9. At one point of time the Lord (Kṛșna) sucked the teats of the ogress $(P \bar{t} \tan \overline{)})$ and when he stole butter he was tied to a mortar that he pulled and caused the two maruta $^{25}$ trees to fall (Yamalārjunabhanga).

10. This hymn ends with exaltation of Kṛṣna as the Lord who admonished Kuvalayapiṭha and Rāma who shattered Lañkà to pieces.

From the above account it is clear the Ālvārs on a number of occasions refer to the daśâvatāras in clusters. It is not clear whether the Sanskritic literary sources meet such a need for bringing together the avatāras into a capsule.

\section{Sculptural Presentations}

The images in the Srīvaikuntham temple are arranged in the following conventional order: Matsya, Kürma, Varāha, Nṛsimiha, Vāmana, Paraśurāma, Dāśarathi-Rāma, Balarāma, Kṛṣna and Kalki.

\footnotetext{
${ }^{24}$ This is a rare instance of the Lord associated with three Devīs (cf. Kalidos 2010). Prof. Raju Kalidos has reported an image of Garuḍārūạa-Viṣnu with three Devīs and identifies the third with Nappinnai.

${ }^{25}$ Queen's flower tree (Terminalia arjuna). According to the Bhāgavata Purāna (Skanda 10, Chap. 10), Kṛṣna pulled down the Arjuna trees that were the guhyakas, Nalakubara and Manigrīva, cursed to be trees and redeemed them (Kalidos 2006: I, 43).
} 
Matsya and Kürma are in zoomorphic form. The images being under active worship, it was not possible for us to remove the garments that cover the images. Matsya has the big head of a local variety of carp fish, Tamil kentai (supra) (fig. 1). The head alone is visible. Kürma is also zoomorphic. The head peeps out of its shell (fig. 1). Varāha is theriomorphic (fig. 1). The Lord is seated in sukhāsana. He has a human body, fitted with the head of a Boar. The head is decked with a karandamakuta. The hands are four. The parahastas bear the cakra and śankha. The pürvahastas are in abhaya- and varada- mudrās. Bhūdevī is missing. This type of kevala image is called PralayaVarāha that appears in the garbhagṛha of the Śrimușnam temple (Rajarajan 2006: 70-72).

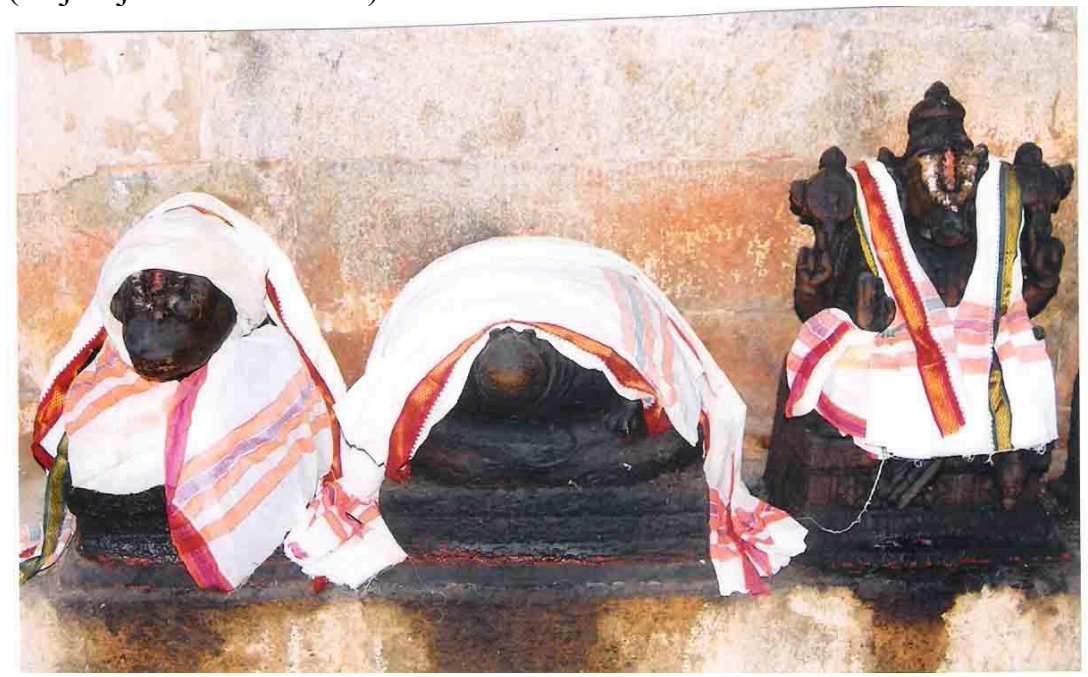

Figure 1. Matsya, Kūrma and Varāha, Kaḷarpirān temple, Śrīvaikuṇṭam. 


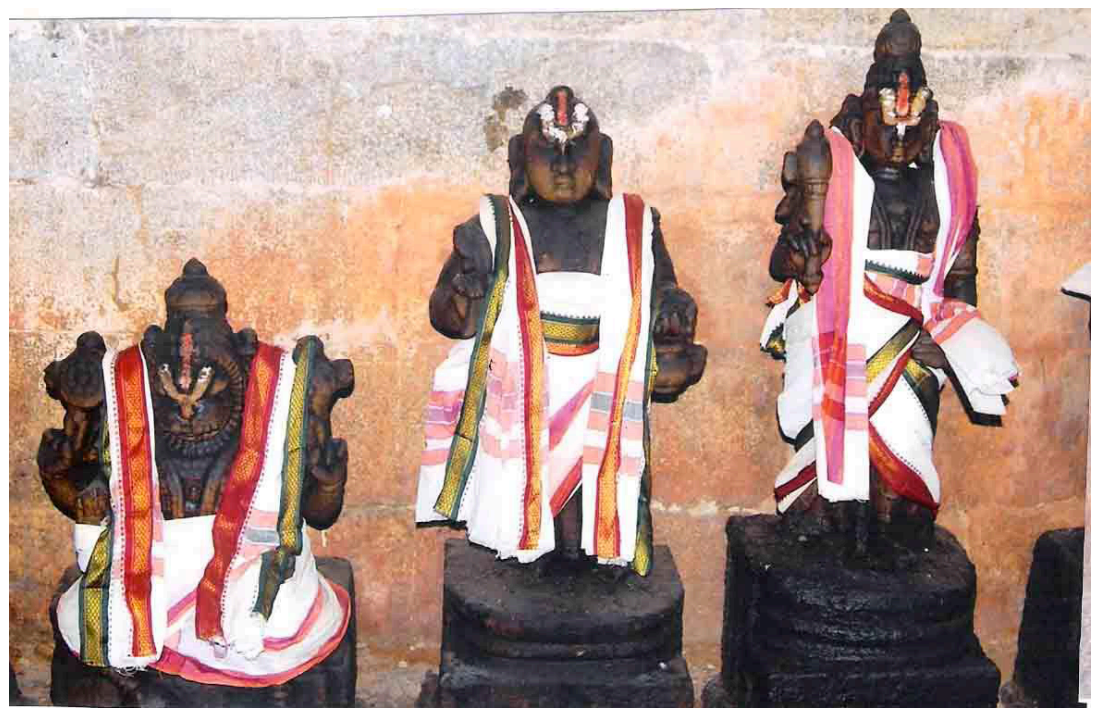

Figure 2. Nṛsimha, Vāmana and Paraśurāma, Śrīvaikunțham temple.

Nṛsimha is cast in the same mould as Varāha (fig. 2). Theriomorphic, he has a lion head and human body. The mane around the face is arranged in a circular fashion. The head is fitted with a karandmakuta. Seated in sukhāsana, the hands are four. The parahastas hold the cakra and śankha. The pürvahastas are in abhaya- and varadamudras. Lakșmī is missing and so he may be called Yoga-Nrsimima or Kevala-Nṛsimha.

Vāmana is a Dwarf (cf. the other images of Paraśurāma to Kalki iconometrically). His head is shaven like a brahmacāri (fig. 2). Twoarmed, he seems to hold a puștaka in the right hand and kamandalu in left hand. The image is samapāda-sthānaka.

Paraśurāma is also two-armed (fig. 2). He holds the paraśu in right hand and the left is in ūruhasta mode. He wears a karandamakuta. The image is samapāda-sthānaka. Śri Rāma holds the dhanus and bāna is two of his hands (fig. 3). The image is slightly dvibhanga. The Lord wears a kirițamakuta. Balarāma holds the haläyudha in his right arm. The left hand is rested on a gadā. He wears a kiritamakuṭ. The image is samapāda-sthānaka. 
Kṛșna is also two-armed (fig. 4). The right arm seems to hold a centu "horsewhip". The right arm carries a lump of butter. The headgear is peculiar and arranged like a bun. It is called krnsankontai (bun of Kṛsna) in Tamil. This type of bun became popular in the art of the Vijayanagara-Nāyakas. The images of Ānțāl are set with this type of headgear in Tamilnadu (Rajarajan 2006: II, pl. 72: Āṇțāl in Kālamēkap Perumāl Temple, Tirumōkūr, near Maturai).

Kalki is horse-faced (fig. 4). His body below neck is human. He is two-armed and carries the khadga and khetaka in right and left hands. He wears a kìrịtamakuta.

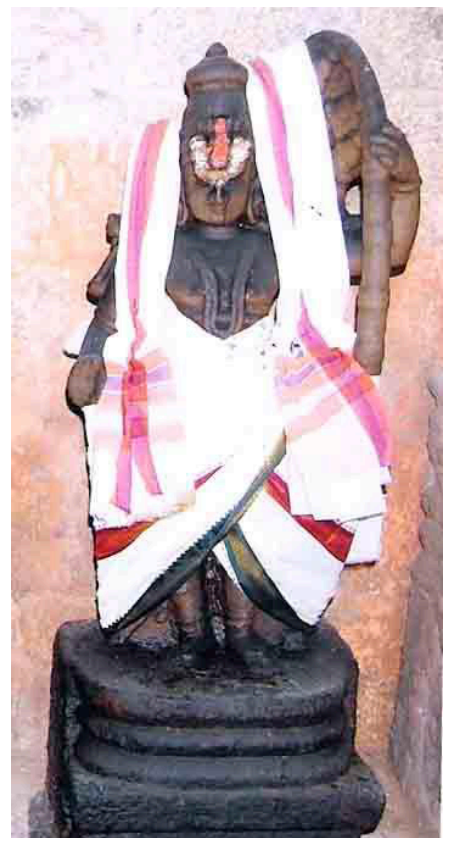

Figure 3. Dāśarathi-Rāma, Srīvaikuntham temple.

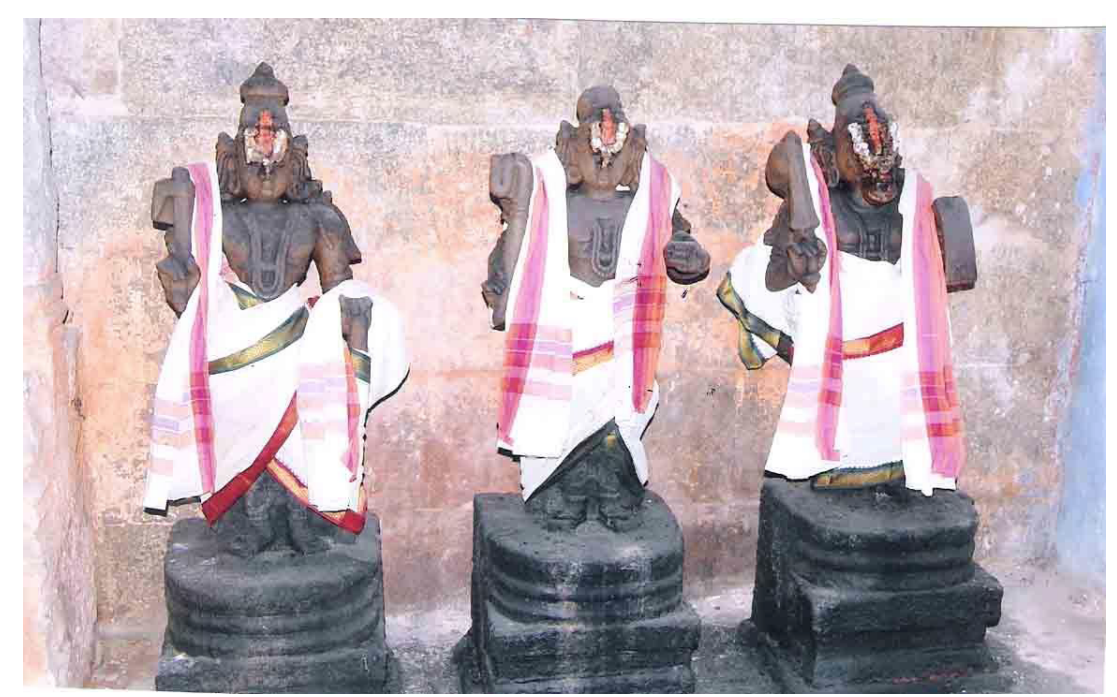

Figure 4. Balarāma, Kṛṣna and Kalki, Śrīvaikuṇṭham temple. 
It is interesting to note that excepting Varāha and Nrsimha all others are dvibhuja. Very interestingly, the Tamil bhakti hymns associate Paraśurāma with three Devīs. In sculptural art, he is never accompanied by Devīs.

The images in the Tatitikopu temple are housed close to the tirumatil (wall of the inner prākāra) at the edge of the Rangamandapa of the Tāyār shrine (Gopalakrishnan 1996: Plan 2). ${ }^{26}$ Matsya and Kürma are zoomorphic. Varāha is fitted with the face of a boar and theriomorphic. He is four-armed and carries the cakra and sankha in parahastas. Vāmama, Paraśurāma, Śrī Rāma, Balarāma and Kṛ̣ṇa are cast in the same mould as in the Vaikuntam temple. It appears the same silpācāryas have worked in the two temples. Kalki is seated on a galloping horse, carrying the sword and shield in hands.

It is very interesting to note that in the place of Nrsimha, Hayagrīva with horse-face appears. He is theriomorphic. Seated in sukhāsana, he carries the cakra and śankha in parahastas. Hayagrīva replacing Nrsimha is an iconographic marvel that has its roots in the Tamil bhakti hymns (supra). ${ }^{27}$

In conclusion it may be added that the type of Daśävatāra images in a sequence has its roots in the Tamil bhkati tradition. One set of stone images alone could be reported with photographic evidence in the present article since the other images in the Tāțikkompu and Alākarkōyil temples are strictly prohibited for photography. Few clusters have been reported from the temple cars of Tamilnāḍu (Kalidos 1989: fig. 36 of Matsya, Kūrma and Varāha \& 43 the three Rāmas). More such images could be discovered if a systematic survey is undertaken.

\footnotetext{
${ }^{26}$ The temple has undergone drastic renovation since S. Gopalakrishnan wrote his article in 1995, published in the East and West 1996. Another wall has been added and some modern buildings built. The original temple's format has not been altered in any way. Dr R.K.K. Rajarajan is working with another paper on the changing phase of the Tătikkompu temple.

${ }^{27}$ The temple administration did not allow us to make a photo during a recent visit.
} 


\section{References}

Basham, A.L. (1971) The Wonder that was India. Rupa \& Co., Calcutta.

Caturvimś́atimūrtilakșaṇa, Sarasvatī Mahal Library, Thanjavur 2002.

Chandramohan, P. (2008) Garuḍa in Medieval Art \& Mythology. Sharada Publishing House, Delhi.

Gail, Adalbert J. (1983) On the Symbolism of Three and Four-faced Viṣnu Images: A Reconsideration of Evidence. Artibus Asiae, Vol 44:4, pp. 297-307.

Ganeshram, S. (2010) Vaiṣnava Divyakșetras in the Southern Pāndya Country (Ph.D. thesis, Madurai Kamaraj University). Madurai.

Gopalakrishnan, S. (1996) The Ranga-maṇdapa of the Tațikkompu Temple A Study of an Iconographic Programme of the Vijayanagara Tradition. East and West, Vol. 46: 3-4, pp. 41532, figs.

Kalidos, Raju (1986) Viṣnu’s Mohinī Incarnation: An Iconographical and Sexological Study. East and West, Vol. 36: 1-3, pp. 183204.

(1988) The Wood Carvings of Tamilnadu: An Iconographical Survey. Journal of the Royal Asiatic Society of Great Britain and Ireland, No. 1, pp. 98-125.

(1989) Temple Cars of Medieval Tamilaham. Vijay Publications, Madurai.

(1997) Antiquity of Tillai-Cittirakūțam. South Asian Studies, Vol. 13, pp. 17-24.

(1999) Nrsimha in Early Medieval Literature and South Indian Art. Annali dell' Istituto Orientale, Vol. 59: 1-4, pp. 168-82.

(2006) Encyclopedia of Hindu Iconography: Early Medieval, Vol. I Viṣnu. Sharada Publishing House, Delhi. 
(2010) Tamil Literary Traditions: their relevance in the Study of Indian Arts. Conference Paper: Exploring Indian Culture. A Collection of Essays in History, Art and Literature. Rome.

Kannan, K. (2007) Viṣnu Temples of the Tiruvārūr Region (Ph. D. thesis, The Tamil University). Thanjavur.

KA: Krsṣnāṣtottara. In Anadimangalam K. Narayanasvami Ayyar ed. Sarvadevatāștottarasadanāmāvalimālā, Chennai 1990.

Maxwell, T.S. (1983) The Evidence for a Viśvarūpa Iconographic Tradition in Western India, 6th-9th Centuries A.D. Artibus Asiae, Vol. 44:3, pp. 213-34.

(1993) A Gūrjara-Pratīhāra Image of Viṣnu Viśvarūpa. Art the Integral Vision (A Volume of Essays in Felicitation of Kapila Vatsyayan), pp. 97-110. New Delhi.

NA: Nrsimhātttottara. In Anadimangalam K. Narayanasvami Ayyar (supra).

Nālāyiram: Nālāyirativviyappirapantam, Māyan Patippakam (Publications), Chennai n.d.

- The Little Flower Company, Chennai 1984/2008.

4 vols. with summary in prose M. Narayana Velu Pillai, Mullai Nilayam, Chennai 2000/2008.

Nānnmukan Tiruvantāti of Tirumalicai Ālvār, part of Nālāyiram.

Rabe, Michael D. (2001) The Great Penance at Mãmallapuram. Intitute of Asian Studies, Chemmanjeri/Chennai.

Rajarajan, R.K.K. (1995) Alakarkoyil in Literature and Art (Masters' thesis, Madurai Kamaraj University). Madurai.

(2006) Art of the Vijayanagara-Nāyakas: Architecture and Iconography, 2 vols. Sharada Publishing House, Delhi.

Rāmāyaṇam of Kampar, Kampan Kalakam ed., Chennai 1976/1977.

Srinivasan, K.R. (1964) Cave Temples of the Pallavas. Archaeological Survey of India, New Delhi.

Williams, Joanna G. (1983) The Art of Gupta India: Empire and Province. Heritage Publishers, New Delhi. 